\title{
Politikk og kriminalitet i det nye Tyrkia
}

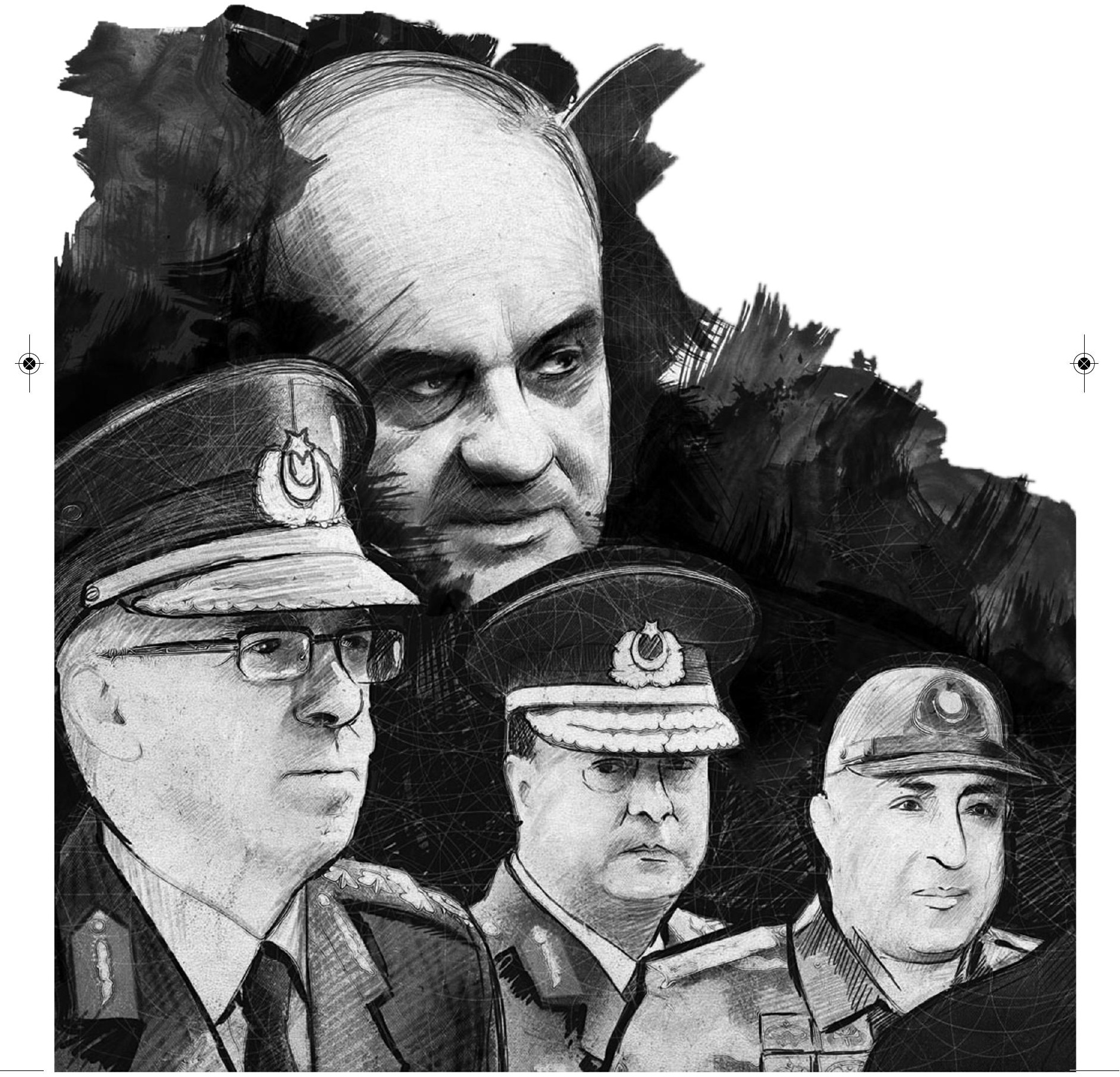




\section{I løpet av AKPs ti år i regjering har tusenvis blitt fengslet for sine politiske synspunkter. Opposisjonen hevder at domstol- ene løper AKPs ærend, mens AKP hevder de er etterlevninger av det gamle militærregimet. Begge har delvis rett.} ved University of Washington. Han har en cand.mag. i statsvitenskap og master i tyrkisk fra Universitetet i Oslo.

VEIEN FRA FENGSEL til regjering kan være kort i Tyrkia. I I999 ble Istanbuls borgermester Recep Tayyip Erdogan fengslet i fire måneder og utestengt fra politiske verv på livstid av en halvmilitær statssikkerhetsdomstol for å ha spredd islamistisk propaganda. To år senere stiftet han Rettferdighets- og utviklingspartiet (Adalet ve Kalkınma Partisi, forkortet til AKP) og gikk til valg med løfter om å redusere militærets innflytelse og styrke religiøse og kulturelle rettigheter. Aldri mer skulle politikere som Erdogan settes bak lås og slå for sine overbevisninger. AKP vant valget i 2002, opphevet forbudet mot politiske verv og gjorde Erdogan til statsminister.

Ti år senere er grensen mellom politikk og forbrytelse fremdeles like flyktig, men nå er det ikke lenger Erdogan som står tiltalt. AKP har riktignok gjennomført viktige reformer. I

tillegg til å stable økonomien på beina har partiet lettet på restriksjonene på kurdisk språkbruk i media og minsket sa

\section{na.}
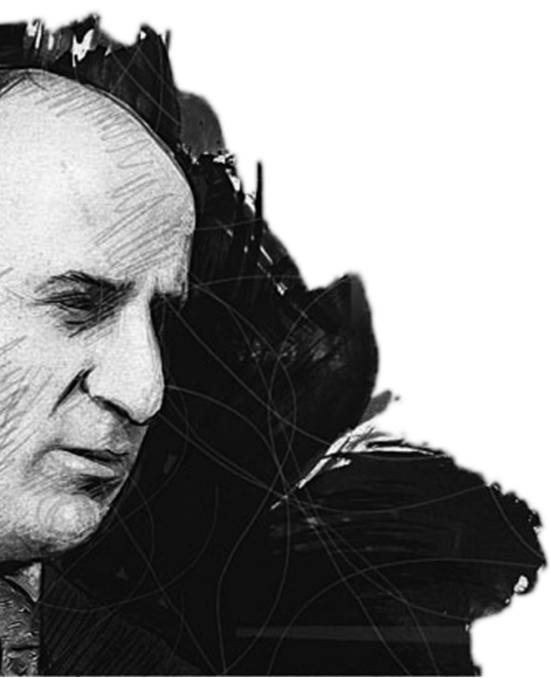

militærets innflytelse over politikken. Samtidig har reformene skapt grobunn for utfordringer for AKPs nyvunne dominans. Avmilitariseringen førte til murring blant generalene, som så på seg selv som vokterne av det tyrkiske regimets sekularisme. ${ }^{.}$Murringen økte til trusler om militær intervensjon i 2007 da AKP forsøkte, og tilslutt lyktes, å få sin kandidat Abdullah Gül valgt til president. En annen utfordring var kurderne. Den forsiktige åpningen mot kurdisk identitet førte til at kurdiske velgere lettere kunne mobiliseres av pro-kurdiske partier. Ettersom kurdere lenge har vært en av de islamistiske partienes viktigste støttespillere sørøst i Tyrkia, ${ }^{2}$ var de kurdiske partienes fremvekst en trussel mot AKPs hegemoni. Det vakte særlig uro da Partiet for demokratisk samfunn (Demokratik Toplum Partisi, DTP) fikk flertall i åtte sørøstlige provinser ved lokalvalgene i 2009 .

Under AKP har begge disse utfordringene blitt møtt med samme våpen: domstolene. I løpet av AKPs ti år i regjering har tusener av kurdiske parlamentarikere og lokalpolitikere, kritiske journalister, studenter, akademikere og militæroffiserer lidd samme skjebne som Erdogan led før han ble statsminister. Resultatet er paradoksalt. Det var AKP som grunnlovsfestet at internasjonale lovverk som Den

Flere av de tiltalte i Ergenekon-saken er offiserer. Illustrasjon hentet fra et tyrkisk magasin. 
europeiske menneskerettighetskonvensjonen har presedens over tyrkisk lovgivning, men AKPs Tyrkia er fremdeles det landet med flest dommer mot seg i Den europeiske menneskerettighetsdomstolen. ${ }^{3}$ AKP har liberalisert lovgivningen rundt offentlige uttrykk for religiøs og etnisk tilhørighet, men samtidig har forholdene for journalister og akademikere blitt stadig vanskeligere. ${ }^{4}$

For APK har domstolene vært både en velsignelse og en kilde til forlegenhet. Opposisjonen mener at domstolene løper AKPs ærend. Erdogan avfeier kritikken med at regjeringen hverken kan eller bør blande seg inn i pågående rettssaker, og at problemene skyldes autoritære dommere og et foreldet lovverk som AKP uansett er i ferd med å endre. Likevel er det vanskelig å ikke legge merke til partiets somling med å liberalisere straffelov-

\section{$\odot \odot \odot$ \\ For AKP har domstolene voert \\ både en velsignelse og en kilde til forlegenhet. \\ $\odot \odot \odot$}

en og å fjerne de «spesielle» domstolene som har overlevd siden republikkens første leveår.

I denne artikkelen skal jeg forsøke å vise at både AKP og deres kritikere har delvis rett. De mange rettssakene mot politikere, journalister, studenter og militæroffiserer under AKP er i aller høyeste grad politisk motiverte; de er imidlertid ikke politisk instruerte. Den flertydige ordlyden i den tyrkiske straffelovgivningens paragrafer om organiserte politiske forbrytelser har lenge gitt dommere stor handlefrihet til å slå ned på politiske motstandere. Siden militærkuppet i I980 har rettssystemet dessuten vært dominert av militærvennlige jurister som ser venstreorienterte, kurdere, og islamister som trusler mot statens sikkerhet. Men som statsvitere innenfor den ny-institusjonalistiske skolen viser, kan flertydige regelverk også utnyttes av motstandere av de som opprinnelig skapte reglene. ${ }^{5}$ Etter at AKP tok makten har partiet gjort lite for å liberalisere rettssystemet, utover å redusere militærets innflytelse over de «spesielle» domstolene som håndterer politiske forbrytelser. Resultatet er at militæret har overtatt islamistenes plass på anklagebenken, mens rettssakene mot venstreradikale og kurdere kan fortsette som før.

\section{Politiske domstoler}

Straffedomstoler er i utgangspunktet ambivalente institusjoner. På den ene siden er de ofte politiske, ettersom lovanvendelse gjerne innebærer en tolkning med flere mulige utfall. ${ }^{6}$ På den annen side er domstolenes autoritet avhengig av at de fornekter sin politiske rolle. ${ }^{7}$ I motsetning til politikere, skal dommere anvende en nøkternt utformet straffelov så tekstnært og nøytralt som mulig. Idealet om nøytralitet og uavhengighet eliminerer ikke det uunngåelige forhold at dommere inngår i en sosial og politisk sammenheng, men det gjør at eventuell politisk maktutøvelse må skje innenfor et begrenset repertoar av allment utformede argumenter og regulære prosedyrer. ${ }^{8}$ Domstolenes makt er derfor en flertydig ressurs: i prinsippet lik for alle, men i praksis foranderlig og manipulerbar for politiske formål så lenge en viss institusjonell kontinuitet ivaretas. ${ }^{9}$

Tyrkias makthavere har brukt flere metoder for å forme straffedomstolene til politiske redskap. Den mest åpenbare metoden er å endre straffeloven. Takket være Tyrkias brokete politiske fortid byr tyrkisk straffelovgiv- 
ning på mange muligheter til å kriminalisere opposisjon. Tyrkias første straffelov fra 1926 var nesten direkte kopiert fra den italienske straffeloven. Den italienske loven var på den tiden kjent som en av de mer liberale og moderne straffelovene, men ble i i930 tilført autoritære elementer under Mussolinis styre. I I936 valgte Tyrkias makthavere igjen å følge italienernes eksempel, og kopierte mye av Mussolinis lovendringer inn i sin egen straffelov. ${ }^{10}$ Resultatet ble en lov som la større vekt på å beskytte staten og nasjonalfølelsen enn den individuelle borger. Særlig sosialisme, definert som forsøk på å «gjøre én samfunnsklasse til hersker over andre klasser» var nå regnet som en trussel mot nasjonens sikkerhet. ${ }^{\text {II }}$

Straffeloven gjennomgikk en mengde mindre endringer etter overgangen til demokrati i i950. Men til tross for stadige valgløfter skjønte de største partiene at vagt definerte politiske forbud med fordel kunne beholdes for å holde i sjakk de etterhvert mange mindre partiene av ulike politiske, etniske og religiøse avskygninger. Istedet forflyttet kampen seg til lovens håndhevere: dommerne og aktorene.

På samme måte som straffeloven tidlig utviklet autoritære trekk, utdannet Tyrkias ledere under mellomkrigstiden jurister som først og fremst regnet seg selv som beskyttere av staten. ${ }^{\mathrm{I2}}$ Den tyrkiske nasjonalstaten var ennå ung og sårbar overfor fiender, både innenfor og utenfor landets grenser. Statslederne så det derfor som sin oppgave å skape et rettssystem som oppfylte to til dels motstridende kriterier: moderne og uavhengig, men også såpass lojalt til staten at domstolene ikke ble talerstoler for politiske dissidenter eller redskaper for utenlandske interesser. ${ }^{13}$ Selv forsvarsadvokater måtte sverge troskap til den tyrkiske nasjon, ${ }^{\mathrm{I}}$ og måtte love å holde seg strengt til tekniske argumenter hvis klienten de for- svarte var tiltalt for politiske forbrytelser. Det var tross alt «denne nasjonen som har skapt advokaten», ikke omvendt. ${ }^{15}$

Først med den politiske polariseringen av samfunnet på ı96o-tallet utviklet unge jurister, som mange andre unge i Tyrkia, en politisk bevissthet som ikke nødvendigvis stod i samsvar med den offisielle statsideologien. ${ }^{16}$ Universitetene ble viktige senter for aktivisme, og mange venstreradikale kom fra nettopp jussfakultetene. Med sterke profesjonelle bånd til akademia kunne ikke dommerstanden unngå å velge side. For politikerne ble det derfor om å gjøre å plassere deres «egne» jurister i viktige stillinger etterhvert som dommere og aktorer gikk av med pensjon eller ble overført til andre stillinger.

Saken stilte seg annerledes for militæret. Tyrkias domstolssystem var fra begynnelsen av basert på det franske, og skiller derfor mellom det «ordinære» rettsapparatet, som inkluderer både sivil- og straffedomstoler, og det administrative rettsapparatet, som har ansvar for saker som involverer den offentlige administrasjonen. I tillegg finnes militære domstoler, som i utgangspunktet var strengt begrenset til disiplinærsaker innad i militæret i fredstid, men som også kunne utvides til visse forbrytelser begått av sivile i sammenheng med krig eller unntakstilstand. Dette endret seg imidlertid mot slutten av 6o-tallet, da militærledelsen med økende uro merket at venstreradikale begynte å få gehør blant militærets yngre garde. I ig69 ble fem «revolusjonære offiserer» kastet ut av marinen. Offiserene gikk rettens vei for å få tilbake stillingene, med det resultat at Den administrative høyesterett gjeninnsatte dem. ${ }^{\text {17 }}$ Selv med allierte på høyresiden i partipolitikken kunne ikke militærledelsen erstatte alle de venstreorienterte dommerne raskt nok til å bruke 
domstolene som politiske våpen; domstolene var tvert imot en hindring. I I970 valgte militærledelsen derfor å bruke sine egne domstoler, som normalt bare skulle brukes innad i militæret, mot sivile studenter og fagforeningsfolk. Militære rettssaker av sivile kom for alvor i gang etter at høyreorienterte generaler foretok et militærkupp i I97I for å komme de mer venstreorienterte offiserene i forkjøpet. Blant de første venstreradikale som ble dømt til døden var jusstudenten Deniz Gezmis.

Ettersom militære dommere er underlagt

\section{$\odot \odot \odot$}

Al-Qaida i Irak har gitt ut 542 filmer. 381 av disse viser et angrep, og 204 et kjøretøy som kjørte på en veibombe.

$\odot \odot \odot$

militærhierarkiet og deler mange av oppfatningene til militærledelsen kan de brukes både for å slå ned på politisk opposisjon og for å beskytte offiserer når de står tiltalt for overgrep eller illegale aktiviteter. ${ }^{18}$ Militæret har tatt flere skritt for å forhindre at politikere innskrenker denne kontrollen. Etter kuppet i I97I fikk det militære rettsapparatet sin egen administrative domstol for å forhindre at de sivile administrative domstolene skulle kunne la fremtidige «revolusjonære offiserer» få fotfeste i militæret. I tillegg opprettet militæret en ny kategori av permanente, halvmilitære «statssikkerhetsdomstoler», som fikk ansvaret for politiske forbrytelser begått av sivile i fredstid. Statssikkerhetsdomstolene møtte enorm motstand fra jurister og ble lagt ned av Grunnlovsdomstolen i i976. Først etter militærkuppet i I980, da militæret skrev en helt ny grunnlov, ble de et fast innslag. Etter I980 la militæret seg dessuten på en mer radikal linje, og avskjediget tusenvis av jurister, byråkrater, professorer og andre som kunne mistenkes for ha venstreradikale sympatier. Dommere i hele rettssystemet ble erstattet med militærvennlige jurister. Grunnlovsdomstolen ble dramatisk mer autoritær etter I980, 19 og over de neste 20 årene ble titusener stilt for retten for politiske forbrytelser, først i militærdomstoler, så i statssikkerhetsdomstoler, og etter hvert også i de ordinære straffedomstolene. Det store flertallet var venstreorienterte, ${ }^{20}$ men også islamistiske politikere som Erdogan fikk gjennomgå en gang i blant.

\section{Semdinli og Ergenekon}

Det var altså etter flere tiår med halvmilitært styre, årelange politiske rettssaker og økonomisk krise at AKP ble valgt inn i regjering $i$ november 2002. AKP hadde lenge vært kritiske til straffelovens politiske paragrafer, ${ }^{2 \mathrm{I}} \mathrm{og}$ satte derfor straks i gang med å skrive en ny straffelov, som ble ferdigstilt i $2004 .{ }^{22}$ Til tross for viktige forskjeller var det imidlertid lite endring å spore når det gjaldt politiske forbrytelser. ${ }^{23}$ Nobelprisvinner i litteratur Orhan Pamuk gjorde den nye straffelovens paragraf 30I verdensberømt da han ble tiltalt for å «offentlig snakke nedsettende om den tyrkiske nasjon», men den nye loven har også mange andre overlevninger. ${ }^{24}$ Paragraf 216 viderefører den gamle lovens forbud mot «ytringer som oppfordrer til hat basert på klasse, religion eller rase», den samme forbrytelsen som Erdogan og tusenvis av andre sosialistiske, kurdiske og religiøse aktivister var blitt dømt for opp gjennom årene. Paragraf 302 straffer forsøk på å «ødelegge statens enhet» med minst 30 års fengsel. Paragraf 3I4 gjør det fornuftig nok straffbart å danne en væpnet organisasjon med formål å angripe statens institusjoner, men andre paragrafer og til- 
leggslover gjør at man kan dømmes som aktivt organisasjonsmedlem selv om man bare har «hjulpet» den (paragraf 220/7) eller sågar deltatt i støttedemonstrasjoner (Terrorismelovens paragraf $7 / 2) .{ }^{25}$

AKP har dermed bevart de egenskapene som gjør det mulig å ilegge strenge straffer for forholdsvis uskyldige politiske handlinger. Men, som forsvarere av loven påpeker, kan ikke de verste resultatene skyldes utelukkende på selve lovteksten, som i noen tilfeller er kopiert direkte fra europeiske lover. ${ }^{26}$ Mye beror også på domstolenes ansvarsområde, struktur og forhold til resten av staten. Også her var AKP ambivalente. Partiet avskaffet statssikkerhetsdomstolene i 2004, men opprettet samtidig en ny kategori av sivile «Domstoler med særskilte fullmakter» (Özel Yetkili Mahkemeler, forkortet ÖYM). ${ }^{27}$ ÖYM fikk ansvaret for det som i den nye straffeloven var definert som «forbrytelser mot statens sikkerhet» og «forbrytelser mot den konstitusjonelle orden» (herunder paragraf 302 og 3I4). Med hensyn til ansvarsområde var ÖYM-domstolene derfor i stor grad en fortsettelse av tidligere tiders politiske domstoler. ${ }^{28}$ Forskjellene er imidlertid like viktige som likhetene. Mens både militær- og statssikkerhetsdomstolene hadde militære dommere på podiet, var ÖYM kun bemannet av sivile. Disse hadde i tillegg større makt enn vanlige jurister. Mens andre domstoler måtte holde seg til sine strengt avgrensede kompetanseområder, kunne ÖYM-domstolene utføre sitt arbeid uten hensyn til de mistenktes stilling eller rang, om det så var i militæret, etterretningstjenesten, eller byråkratiet.

ÖYM-domstolene hadde knapt eksistert i ett år før de gjorde seg bemerket. Mot slutten av 2005 oppdaget etterforskere i byen Semdinli sørøst i Tyrkia at mange av bombeatten- tatene som hadde skjedd i området siden juli ikke var utført av den kurdiske separatistorganisasjonen PKK, slik man tidligere hadde antatt, men av sivilkledde medlemmer av gendarmeriet. En ung aktor med «særskilte fullmakter» ble satt til å fortsette etterforskningen. Militærledelsen var som vanlig lite samarbeidsvillig, og flere generaler gikk sågar ut med støtte til de tiltalte.

Overraskelsen var derfor stor da aktor presenterte den endelige tiltalen i mars 2006 . Han anklaget to medlemmer av gendarmeriet og en sivil medsammensvoren ikke bare for drap, men også for den politiske forbrytelsen å ha forbrutt seg mot «enheten av staten og nasjonen» etter straffelovens paragraf 302. Han resonnerte at offiserene, som egentlig hadde i oppdrag å beskytte den tyrkiske statens enhet ved å bekjempe kurdisk separatisme, istedet forsøkte å «skape forvirring, ødelegge den offentlige orden og tilslutt også statens enhet» med bombene. ${ }^{29}$ Enda mer overraskende var at aktor insinuerte at militærled elsen med vitende og vilje beskyttet de tiltalte.

Reaksjonen fra den eldre garde i rettsystemet lot ikke vente på seg. Det høye rådet for dommere og aktorer (Hakimler ve Savcilar Yüksek Kurulu, HSYK), organet som utnevner og disiplinerer jurister i hele det sivile rettsystemet, avskjediget aktoren. Domstolen fortsatte likevel med saken, og dømte til slutt alle de tre tiltalte til 40 års fengsel. Som straff sendte HSYK dommerne i «eksil» ved å overføre dem til andre provinser. De tiltalte anket samtidig dommen til Høyesterett, som besluttet at saken tilhørte det militære rettssystemet og derfor måtte begynne på nytt igjen. Allerede første dag av rettsaken løslot den militære domstolen alle de tre tiltalte. ${ }^{3 \circ}$

Militæret vant dermed den første kampen, men krigen hadde bare såvidt begynt. I juni 
2007, mens debatten omkring Abdullah Güls presidentkandidatur pågikk for fullt, ble politietterforskere i Istanbul tipset om at det befant seg håndgranater og utstyr til produksjon av bomber $\mathrm{i}$ et forlatt hus $\mathrm{i}$ nabolaget Ümraniye. Avhør av husets eier førte etterforskerne til to pensjonerte militæroffiserer, som ble satt i varetekt mens hjemmene deres ble ransaket. Etterforskningen begynte snart å peke lenger inn i militærets rekker, noe som gjorde det nødvendig å utnevne en aktor med «særskilte fullmakter». Han presenterte den første tiltalen i juli $2008 .{ }^{35}$ Blant de 86 tiltalte fantes offiserer, journalister og akademikere, de fleste anklaget etter straffelovens paragraf 3 I2 for å ha planlagt å avsette regjeringen ved hjelp av vold, straffbart med minst 30 års fengsel, samt for å ha dannet en væpnet organisasjon med samme formål, en forbryt-

$$
\odot \odot \odot
$$

Ofte styrte al-Qaida i Irak områder ved hjelp av tvang og drap på de som kunne true deres posisjon.

$$
\odot \odot \odot
$$

else som i følge paragraf 3I4 innebærer opptil I5 års tilleggsstraff.

Det er ikke vanskelig å tenke seg at ihvertfall noen av de tiltalte kan ha planlagt å avsette AKP-regjeringen. Noen av dem er gamle kjenninger fra den «dype staten» og har vært involvert i ulovlige politiske aktiviteter før. Gitt at militæret så sent som i 2007 sendte truende signaler, er heller ikke tanken om et militærkupp helt søkt. Fra et juridisk standpunkt er imidlertid ikke løse antagelser nok. Som Gareth Jenkins påpeker, er bevisgrunnlaget for mistanken mot flertallet av de tiltalte forsvinnende tynt..32 Bortsett fra de første tiltalte, er de fleste av dem simpelthen nevnt $\mathrm{i}$ forbifarten under avhør, i løpet av avlyttede telefonsamtaler eller i dokumenter funnet $i$ andre tiltaltes hjem. Hovedbeviset er et konspiratorisk dokument med uviss forfatter, funnet hjemme hos en eksentriker som hevder å ha jobbet for Etterretningstjenesten (noe Etterretningstjenesten benekter), og som siden har rømt til Canada, blitt kristen, og til slutt jødisk. ${ }^{33}$

Som juridisk dokument er tiltalen derfor veldig svak. Som litteratur, derimot, er den imponerende. På nesten 2500 A4-sider legger aktor frem bevismaterialet i kronologisk orden som en fortelling om selve etterforskningsprosessen. Den tålmodige leser blir dermed vitne til at en håndfull kriminelle gradvis utvides til et spindelvev av medsammensvorne hvis innbyrdes forhold til dels bare insinueres. At forbindelsene er vanskelige å bevise ligger ifølge aktor i sakens natur: Det var nettopp giennom tilsynelatende ukoordinert propaganda og villedende «falskt flagg»operasjoner at Ergenekon skulle skape kaos og rettferdiggjøre et militærkupp. Organisert propaganda er derfor til forveksling lik politisk polemikk.

Mellom 2008 og 20II ble tiltalen gradvis utvidet som resultatet av en stadig bredere etterforskning, og omfattet tilslutt II2 tiltalte. Samtidig ble flere tiltaler ferdiggjort. I 2009 kom et tiltaledokument med 56 anklagede, ${ }^{34}$ og den tredje tiltalen kom bare fire måneder senere, med 52 mistenkte. ${ }^{35}$ Flere aktorer kom til for å hjelpe til med en etterforskning som var i ferd med å vokse ut av proporsjoner. I en tiltale datert januar 2010 anklager aktorene I7 personer for å ha planlagt voldelige angrep på ikke-muslimske minoriteter. Angrepene skulle tilskrives tilhengere av AKP og slik rettferdiggiøre et kupp. ${ }^{36}$ Denne tiltalen ble straks 
etter utvidet med først I9, ${ }^{37}$ så 33 mistenkte, slik at den nå omfatter 7I tiltalte, de fleste offiserer i marinen. ${ }^{38} \mathrm{I}$ juli 20 Io kom så en ny, nesten tusen siders tiltale hvor I96 personer, flesteparten høytstående offiserer i hæren, ble anklaget for å ha planlagt et militærkupp med kodenavnet «Slegge».39

Jo mer antallet mistenkte vokste, jo mer begynte Ergenekon-saken å ligne en usannsynlig spionroman med dobbeltagenter på hver side. Blant de mistenkte i tiltalen fra 2009 var Tanju Güvendiren, tidligere aktor i en statssikkerhetsdomstol hvor han hadde vært ansvarlig for flere rettssaker mot organisasjoner, ikke ulikt den han nå selv stod tiltalt for å være medlem av, og Erol Mütercimler, en journalist som var den første til å advare mot et nettverk han kalte «Ergenekon» ti år tidligere. Men sakens kanskje mest overraskende plott-vridning kom i en tiltale fra august 20II. ${ }^{4 \circ}$ Blant de I4 nye som nå stod tiltalt var journalisten Ahmet S1k, som tidligere var blitt stilt for retten for å ha kritisert militærets innblanding i politikken, akademikeren Nedim Sener, som hadde skrevet om etterretningstjenestens rolle i drapet på den armenske redaktøren Hrant Dink i 2007, og den pensjonerte politimesteren Hanefi Avc1, som var kjent for å ha etterforsket kriminelle nettverk innad i staten. Nå stod de tiltalt for samme type aktiviteter som de tidligere hadde viet seg til å bekjempe.

Arrestasjonen av Sik, Sener og Avc1 var dråpen som fikk begeret til å renne over for mange av de som tidligere hadde støttet Ergenekon-etterforskningen, men som ikke nødvendigvis identifiserte seg med AKPs religiøse profil. Fra 20II begynte stadig flere å hevde at ÖYM-domstolene var kontrollert av det islamistiske «Fellesskapet» (Cemaat) ledet av Fethullah Gülen fra hans eksil i USA, en beveg- else som sies å ha infiltrert det tyrkiske rettssystemet og politiet med AKPs velsignelse. ${ }^{41}$ Da Sik ble arrestert, holdt han på med en bok om Gülen-bevegelsens økende makt i politiet og byråkratiet etter at AKP kom til makten. Politiet slettet alle kopier av bokutkastet de kunne finne..$^{42}$ Sener hadde skrevet en bok om Gülen-bevegelsen basert på rapporter fra Ergenekon-etterforskningen, ${ }^{43}$ og Avc1 en bok om hvordan Gülen-bevegelsen har infiltrert politiet. ${ }^{44}$ Aktor tolket bokutkastene og etterforskningsmaterialet som organisasjonsdokumenter som beviste at de tre var medlemmer av Ergenekon. For ÖYM-domstolenes kritikere virket det mer sannsynlig at aktor forsøkte å beskytte sine oppdragsgivere ved å trekke S1k, Sener og Avcı inn i Ergenekon-saken.

\section{Kurdere og venstreradikale}

Med en så radikal omdefinering av rettsystemets formål som Ergenekon-saken innebærer, kan man spørre seg hvorfor militærvennlige jurister ikke har gått sammen om å bekjempe ÖYM-domstolene, slik de venstreorienterte juristene bekjempet statssikkerhetsdomstolene på I970-tallet. Det er her kontinuitet kommer inn i bildet. Institusjonelt sett innebar opprettelsen av ÖYM-domstolene en relativt liten endring $\mathrm{i}$ forhold til sikkerhetsdomstolene. Og selv om det tidligere var uhørt å stille generaler for retten, var jussen som ÖYM-domstolene brukte for å oversette sine konspirasjonsteorier til rettssaker en fortsettelse av den samme fremgangsmåten som militær- og statssikkerhetsdomstolene tidligere hadde fulgt mot politiske motstandere av militæret. De militærvennlige dommerne hadde dermed lite de skulle ha sagt.

Kontinuiteten mellom det «gamle» og det «nye» rettssystemet blir særlig tydelig hvis vi ser på den andre store gruppen av tiltalte: 
kurdere og venstreradikale. Kurdernes forhold til lovverket har på sett og vis vært det motsatte av militærets. Etter militærkuppet i I980 kjempet Det kurdiske arbeiderpartiet, bedre kjent som PKK, en lavintensitetskrig mot den tyrkiske stat som strakk seg fra I984 til slutten av 9o-tallet, med sporadiske oppblussinger frem til idag. Mens den militære unntakstilstanden (Sikıyönetim) etter kuppet ble gradvis hevet fra mesteparten av landet, ble den derfor bare omgjort til en «ekstraordinær tilstand» (Olaganüstü Hal, forkortet OHAL) i de sørøstlige provinsene hvor kurdisk identitet står sterkest. OHAL innebar et tett samarbeid mellom sivile og militære myndigheter, og ga militæret, gendarmeriet og diverse illegale paramilitære styrker stor handlefrihet overfor både militante og fredelige kurdere. Statssikkerhetsdomstolene ble flittig brukt mot mistenkte separatister, og var ofte villige til å bruke vitnemål tvunget frem under tortur. ${ }^{45}$

Mens rettssystemet har gitt sikkerhetsetablissementet immunitet fra rettsforfølgelse, har det derfor samtidig fratatt en hel befolkningsgruppe reell adgang til rettslige garantier. På toppen av rettshierarkiet har også Grunnlovsdomstolen sørget for å stenge alle pro-kurdiske partier som har blitt stiftet siden I990. Det nåværende «Freds- og demokratipartiet» (Barıs ve Demokrati Partisi, forkortet BDP) er arvtakeren til DTP, som ble stengt av Grunnlovsdomstolen noen få måneder etter det fremgangsrike lokalvalget $\mathrm{i}$ 2009. Grunnlovsdomstolens begrunnelse har $i$ alle tilfellene vært at partiene var frontorganisasjoner for PKK.

Siden 2005 har også den utenomparlamentariske kurdiske bevegelsen gjennomgått endringer. Den siste inkarnasjonen er Unionen av Kurdiske Samfunn (Koma Civakên Kurdistan, forkortet KCK), stiftet i mai 2005 med en deklarasjon som beskriver den som «et demokratisk, føderalt og grenseløst system hvor alle, og særlig kvinner, ungdom og arbeidere, kan delta gjennom autonome lokale forsamlinger». ${ }^{46}$ Nøyaktig hva KCK innebærer utover det, er vanskelig å stadfeste. Deklarasjonen sier at PKK er KCKs «ideologiske styrke» (ideolojik gücüdür), men i motsetning til det PKK er kjent for, sier avtalen at

$$
\odot \odot \odot
$$

De groteske halshuggingsvideoene støtte bort potensielle supportere av al-Qaida, sa organisasjonens nestleder.

$\odot \odot \odot$

KCK skal kjempe for en «demokratisk løsning» (demokratik çözüm) på det kurdiske spørsmålet «uten å ty til vold» (zora ve siddete basvurulmadan). KCKs faktiske forhold til det illegale PKK og det legale BDP er derfor uklart.

ÖYM-aktorene har ikke latt denne flertydigheten komme i veien for en god rettssak. KCK-saken begynte i 2009 med en tiltale mot én person, Serdar Zirig. Tiltalen omfatter beskjedne I4 8 sider, men mesteparten av tiltalen dreier seg ikke om Zirig selv, men om den kurdiske bevegelsens historie fra dannelsen av PKK i 1978 til opprettelsen av KCK i 2005, og KCKs aktiviteter frem til 2009. ${ }^{47}$ Aktors formål har muligens vært å forberede folkeopinionen på en langt større bølge av arrestasjoner ved å vise at KCK og BDP i virkeligheten er dekkorganisasjoner for PKK. En mer substansiell tiltale på over 7500 sider kom i juni 20I0, og anklaget I5I tiltalte for medlemskap $i$ en organisasjon som nå ble sagt å ha celler $\mathrm{i}$ alle deler av tyrkisk samfunnsliv, med BDP som en direkte forlengelse 
av organisasjonen. Enda en tiltale med I93 mistenkte kom i mars 2012,48 og måneden etter kom en ny med 50 mistenkte. ${ }^{49}$ Innen juli 2012 hadde antallet anholdte passert 2000.

Som med Ergenekon-etterforskningen hadde aktorene i KCK-saken nå tøyet rettsystemets definisjonsmakt til det ytterste. En stor andel av de anklagede er medlemmer av det legale partiet BDP, andre er fagforeningsledere, og rundt I5O av dem er forsvarsadvokater, enten for Abdullah Öcalan, den fengslede lederen for PKK, eller for andre som står tiltalt $\mathrm{i}$ KCK-saken. De tiltalte som har fått mest oppmerksomhet er akademikeren Büsra Ersanlı og redaktøren Ragıp Zarakolu, som begge anklages for å ha handlet på direkte ordre fra KCK. Beviset mot Ersanlı er at hun deltok i BDPs kommisjon for å utforme forslag til en ny grunnlov, mens Zarakolu skal ha jobbet for å bedre PKKs image gjennom sine publikasjoner. For domstolene har bevismaterialet nå mistet betydning, sammenlignet med det en journalist har kalt en «fiendementalitet» som ser enhver som sympatiserer med kurderne som terrorister..$^{\text {I }}$

Det som gjør disse koplingene mulige er det samme som har gjort Ergenekon-saken mulig: Lover som med hensyn til straffeutmåling definerer «medlemskap» i forbudte organisasjoner veldig bredt og en juridisk tradisjon som setter statens interesser foran borgernes. Tradisjonen har lange røtter; lovene er i flere tilfeller produsert av AKP, men viderefører det gamle lovverkets flertydighet.

En av disse lovhjemlene er Terrorlovens paragraf 7 , som ble endret i 2006 på en slik måte at «propaganda på vegne av en terrororganisasjon» kan straffes med opptil fem års fengsel i tillegg til det man ellers måtte være tiltalt for. «På vegne av» er ikke spesifisert $i$ lovteksten, men en dom i Høyesterett fra 2008 har fastslått at enhver som tar del i en pro-kurdisk demonstrasjon kan antas å ha handlet på direkte oppfordring av PKK, og kan derfor dømmes som et aktivt medlem. Dette har særlig rammet kurdere sørøst i Tyrkia, som i noen tilfeller har blitt dømt til mange års fengsel fordi de er blitt fotografert i løpet av en demonstrasjon med en sten, eller sågar en halv sitron (for å dempe ubehaget ved tåregass), i hånden..$^{2}$

I tillegg til kurdere har Terrorlovens paragraf 7 blitt brukt mot en mengde venstreradikale studenter som har protestert mot AKPs iver etter å privatisere undervisningssektoren. Tallet på de tiltalte studentene varierer, avhengig av hvordan man definerer «student» og på hvilket trinn i rettsprosessen de befinner seg, fra rundt I500 til oppimot Io 000.53 En typisk sak er en hvor åtte ungdommer fikk mellom I og I3 års fengselsstraff for å ha solgt billetter til en konsert med et venstreradikalt band. ${ }^{54}$ Andre har blitt fengslet for å ha holdt pressekonferanser, andre igjen for å ha kastet egg på medlemmer av AKP. Organisasjonen de tiltalte anklages for å være medlemmer av er i de fleste tilfeller «Det revolusjonære folkets redningsparti og -front» (DHKP-C), en militant organisasjon som har vært aktiv siden 8o-tallet. Som i Ergenekon- og KCK-sakene kan imidlertid bevismaterialet være så tynt som en konsertbillett eller en marxistisk bok. Som for virkelig å understreke den historiske linjen fra den militære rettsakene på I970-tallet til idag, har noen også fått strenge fengselsstraffer for å ha holdt minnestunder for Deniz Gezmis, den venstreradikale jusstudenten som ble henrettet i i972.55

\section{Kontinuitet, konversjon og konflikt}

Mens AKPs ti år i regjering har vært en ene- 
stående suksess for økonomiens del, har rettspolitikken vært mer kontroversiell. Valgseieren i 2002 ga AKP en sjanse til å mykne opp statens forhold til politisk islam. Som vi har sett, har partiet tatt skritt for å forhindre at militæret bruker domstolene til å kriminalisere partiets religiøse tilhengere. Samtidig har tusenvis av journalister, kurdiske og venstreradikale blitt fengslet for sine politiske synspunkter.

Jeg har her forsøkt å vise hvordan en institusjon som rettsystemet kan utvise kontinuitet og forandring på en og samme tid. Rettsmakt er en ressurs som kan konverteres til nye politiske formål når nye aktører kommer på banen. Ettersom domstoler er «nøytrale» er de imidlertid også avhengige av at eventuelle endringer i deres politiske rolle ikke kan tolkes som politisk innblanding. AKPs reformer har derfor vært inkrementelle, og har konsentrert seg om å justere domstolenes ansvarsfordeling. Begrunnelsen har vært effektivisering og avmilitarisering, endringer alle bortsett fra militæret kan enes om.

Inntil nylig har denne kombinasjonen av forsiktig reform og passiv avstandstagen vært en effektiv politisk strategi. Mens domstolene har tvunget opposisjonen i kne, har Erdogan med rette kunnet kritisere dem som etterlevninger av et militaristisk regime. Distanseringen har imidlertid en pris, noe Erdogan fikk erfare i februar 20I2, da en aktor med «særskilte fullmakter» kalte direktøren for Etterretningstjenesten (MiT) inn til avhør for påståtte forbindelser til PKK. MiT er direkte tilknyttet statsministerkontoret, og direktøren var håndplukket til stillingen av Erdogan selv. Hendelsen må ha satt et støkk i Erdogan, for få dager senere gjorde AKP i all hast en lovendring som gjorde det obligatorisk for ÖYM-aktorer å innhente tillatelse fra stats- ministeren for å etterforske medlemmer av MiT. Senere har regjeringen gjennomført flere omstruktureringer av domstolene, dels for å unngå lignende episoder, dels for å imøtekomme stadig mer høylytte protester fra det internasjonale samfunn. Den foreløpig siste reformen kom i juli 20I2, og innebar at mange av de arresterte kurderne, akademikerne og studentene kunne løslates fra varetekt mens rettsakene pågikk. Samtidig ble imidlertid MiTs immunitet utvidet til også å gjelde andre organer direkte underlagt statsministerkontoret. Erdogan har dermed nok en gang justert systemet på en slik måte at rettssakene mot AKPs motstandere kan fortsette uten at domstolene truer partiets makt og popularitet. I september 2012 ble 325 av offiserene og generalene tiltalt $i$ «Slegge»-saken dømt til mellom I3 og 20 års fengsel, til tross for stadige påstander om at bevismaterialet er forfalsket.

Om grensen mellom politisk opposisjon og kriminalitet fremdeles er flyktig, er det altså ikke bare fordi etterlevninger av det halvmilitære regimet stikker kjepper i hjulene for AKPs reformer. AKP har presentert seg som militærregimets endelikt, men har samtidig ivaretatt og utnyttet gamle institusjoner for å utmanøvrere ikke bare militæret, men også andre politiske motstandere. Det gjenstår å se hvor lenge partiet kan fortsette slik uten å miste troverdighet blant Tyrkias velgere.

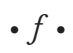

I Tank, Pinar: «Tyrkias militære og 'den dype staten'», i Babylon, nr. I5, 2010, s. 70-79.

2 Çalmuk, Fehmi: Erbakan'ın Kürtleri. Milli Görüs'ün Güneydogu Politikası [Erbakans kurdere. Nasjonalt utsyn-bevegelsens politikk i sørøst]. Istanbul: Metis Yayınları, 200I.

3 European Court of Human Rights, "Violations by Article and by State 20II," http://www.echr.coe.int /NR/rdonlyres/2B783BFF-39C9-455C-B7C7-F821056 BF 32 A/o/TABLEAU_VIOLATIONS_EN_2OII.pdf 


\section{(6.10.2012)}

4 Freedom House rangerer fremdeles Tyrkia som «delvis fri», mens Reporters Without Borders nylig har nedgradert Tyrkia til kategorien med land «under observasjon». Se Freedom in the World 20I2, Freedom House, 20I2, http://www.freedomhouse.org/sites/default/ files/FIW\%2O2012\%20Booklet_o.pdf, og Internet Enemies Report 20I2, Reporters Without Borders, 20I2, http://en.rsf.org/IMG/pdf/rapport-internet2OI2 _ang.pdf.

5 Thelen, Kathleen, og James Mahoney: «A Theory of Gradual Institutional Change» i Explaining Institutional Change: Ambiguity, Agency, and Power. Kathleen Thelen og James Mahoney (red.), s. I-37. Cambridge: Cambridge University Press, 2010.

6 Kennedy, Duncan: A Critique of Abjudication. Cambridge, MA: Harvard University Press, I997.

7 Shapiro, Martin: «Judges as Liars» i Harvard Journal of Law \& Public Policy, nr. I7, I994, s. I55-6.

8 Guarnieri, Carlo: "Judges, Their Careers, and Independence", i Comparative Law and Society. David S. Clark (red.), Northampton, MA.: Edward Elgar Publishing, 2012, s. 193-I95.

9 Jeg låner uttrykket «flertydig ressurs» (ambiguous asset) fra Stark, David: «Ambiguous Assets for Uncertain Environments. Heterarchy in Postsocialist Firms» i Paul DiMaggio (red.), The Twenty-First Century Firm. Changing Economic Organization in International Perspective, s. 69-104. Princeton: Princeton University Press, $200 \mathrm{I}$.

IO Lov nr. 3038, Resmi Gazete [Det offisielle lysningsbladet] nr. 3337, 23.6.1936.

II Lov nr. 765, I926, (med endringene fra juni 1936) bok 2, kapittel 2, del I, paragrafer I4I-I42.

I2 Özman, Aylin: «Law, Ideology and Modernization in Turkey: Kemalist Legal Reforms in Perspective», i Social \& Legal Studies, vol. I9, nr. I, 20I0, s. 67-84.

I3 [Ingen forfatter] Adli Inkilabın Ana Hatlar [Rettsrevolusjonens grunntrekk]. Istanbul: Alaeddin Kiral Basımevi, I937, s. 3-8.

I4 Paragraf 8 i Advokatforeningen i Istanbuls interne ved tekter fra I925. Se Erem, Faruk (red.), Türkiyede Savunma Mesleginin Gelisimi [Advokatyrkets historiske utvikling i Tyrkia]. Istanbul: Türkiye Barolar Birligi Yayınları, vol. I, s. 89

I5 Özkent, Ali Haydar. Avukatın Kitabı [Advokatens bok]. Istanbul: Istanbul Barosu Yayınları, 2000 [1940].

I6 Field, Gary Robert: «Political Involvement and Political Orientations of Turkish Law Students», doktorgradsavhandling, University of Oregon, I964, og Ozankaya, Özer: Üniversite Ögrencilerinin Siyasal Yönelimleri [Universitetsstudentenes politiske orienteringer]. Ankara: Sevinç Matbaası, I966.
I7 Cumhuriyet (dagsavis), 30.0I.I970.

I8 Kardas, Ümit: Hâkim Bagımsızlıgı Açısından Askeri Mahkemelerin Kurulusu Ve Yetkileri [De militære domstolenes struktur og fullmakter i forhold til dommernes uavhengighet]. Istanbul: Kazanc1 Kitap Ticaret, I992, og Crowley, Joseph: «Special Report - Justice on Trial: State Security Courts, Police Impunity, and the Intimidation of Human Rights Defenders in Turkey», i Fordham International Law Journal, vol. 22, nr. 5, I999.

I9 Belge, Ceren: «Friends of the Court: The Republican Alliance and Selective Activism of the Constitutional Court of Turkey», i Law and Society Review, vol. 40, nr. 3, 2006, s. 653-92.

20 Çelenk, Halit: 12 Eylül Ve Hukuk [12. september og loven]. Ankara: Orun Basımevi, 1988, s. 79-83.

2I Se Parslow, Joakim: Turkish Political Parties and the European Union: How Turkish MPs Frame the Issue of Adapting to EU Conditionality. Oslo: ARENA, 2007, s. 7I, der en representant fra AKP kritiserer endringene i den gamle straffelovens paragraf 3 I2 for å ikke gå langt nok i å styrke ytringsfriheten. Det var på grunnlag av paragraf 3I2 at Erdogan ble fengslet i I999.

22 Lov nr. 5237, Resmi Gazete nr. 256II, I2.10.2004.

23 Tellenbach, Silvia: «Zum Neuen Turkischen Strafgesetzbuch», i Konrad-Adenauer-Stiftung Auslandsinformationen, vol. 2I, no. 4, 2005, s. 76-93.

24 En liste over spesielt problematiske paragrafer med hensyn til ytringsfrihet finnes i Ensaroglu, Yılmaz: Freedom of Expression in the New Turkish Penal Code. Ankara: Human Rights Agenda Association, 2006.

25 Terrorismeloven (Terörle Mücadele Kanunu, Lov nr. 3713, Resmi Gazete nr. 20843, I2.4.I99I; endret med Lov nr. 5532, Resmi Gazete nr. 26232, I8.7.2006) spesifiserer en rekke tilleggsstraffer med hensyn til organiserte forbrytelser.

26 Sözüer, Adem: «Die Reform Des Türkischen Strafrechts», i Zeitschrift Für Die Gesamte Strafrechtswissenschaft, vol. II9, nr. 3, 2007, s. 748.

27 Lov nr. 527I, Resmi Gazete nr. 25673, 4.I2.2004.

28 Inanıcı, Haluk: «Örfi Idare Yargısından Yeni Devlet Güvenlik Mahkemelerine Sanık Hakları» [De mistenktes rettigheter, fra krigsrett til statssikkerhetsdomstolene], i Parçalanmıs Adalet: Türkiye'de Özel Ceza Yargisı [Fragmentert justis: Det spesielle strafferettssystemet i Tyrkia]. Haluk Inanıcı (red.), Istanbul: Iletisim, 20II, s. 46-48.

29 For ordens skyld vil jeg her bruke den tyrkiske nummereringskonvensjonen for å referere til tiltaledokumentene: Sorusturma No. 2005/750, Esas No. 2006/32, Karar No. 2006/31, s. 96.

30 En detaljert beskrivelse av dragkampen mellom de lavere og høyere sjiktene av rettsystemet i løpet av Sem- 
dinli-saken fines i Tezcür, Günes Murat: "Judicial Activism in Perilous Times: The Turkish Case", i Law and Society Review, vol. 43, nr. 2, 2009, s. 305-336. Først etter en grunnlovsendring som innskrenket de militære domstolenes jurisdiksjon i 2oro, ble de tre tiltalte sendt tilbake til den opprinnelige domstolen og igjen dømt til 40 års fengsel. II. oktober 20 I2 sendte imidlertid høyesterett saken tilbake til domstolen med begrunnelsen at de tiltalte ikke kan dømmes for organisert politisk virksomhet, bare for drap. Den endelige dommen kommer derfor antageligvis til å bli noe mildere.

3I Iddianame No. $2008 / 623$, Esas No. $2008 / 968$, Sorusturma No. $2007 / 1536$.

32 Jenkins, Gareth: Between Fact and Fantasy: Turkey's Ergenekon Investigation. Washington, D.C.: The CentralAsia-Caucasus Institute \& Silk Road Studies Program, 2009.

33 Ibid., s. 50-55.

34 Sorusturma No. 2009/5II, Esas No. 2009/268, Iddianame No. $2009 / 188$.

35 Sorusturma No. 2009/I498, Esas No 2009/75I, Iddianame No. $2009 / 565$.

36 Sorusturma No. $2009 / 969$, Esas No. 2010/38, Iddianame No. 2010/29.

37 Sorusturma No. 2009/1570, Esas No. 2010/107, Iddianame No. $2010 / 75$.

38 Sorusturma No. $2009 / 2167$, Esas No. 2010/268, Iddianame No. 2010/189.

39 Sorusturma No. $2010 / 185$, Esas No. $2010 / 564$, Iddianame No. $2010 / 420$.

40 Sorusturma No. 20II/1657, Esas No. 2011/605, Iddianame No. 20II/425.

4I Tasçı, Ilhan: Cüppeli Adalet: Hükümet-Cemaat Kusatması [Justis med kappe: Beleiringen av regjeringen og Fellesskapet]. Istanbul: Cumhuriyet Kitapları, 20 Iо.

42 S1ks bok har siden blitt gjort tilgjengelig på internett med tittelen «Imamens hær» (Imamun Ordusu) og «Den som kommer nær, brenner seg» (Dokunan Yanar). Den har også blitt utgitt med tittelen «ooobok» (oookitap, Istanbul: Postacı Yayınevi, 20II), navnet på Word-filen som bokutkastet skal ha hatt. En utgave kan lastes ned fra http://theopinions.info/thearmy oftheimam.htm (I4.8.20I2), og deler er også oversatt til engelsk: http://www.tuerkeiforum.net/enw/index.php /Ahmet_\%C5\%9E\%C4\%Brk:_The_Army_of_the _Imam (I4.8.2012).

43 Sener, Nedim: Ergenekon Belgelerinde Fethullah Gülen Ve Cemaat [Fethulla Gülen og Fellesskapet i Ergenekondokumentene]. Istanbul: Güncel Yayıncilık, 2009.

44 Avcı, Hanefi: Haliç’teli Yasayan Simonlar: Dün Devlet Bugün Cemaat [Tilhengere ved Det gyldne horn: Staten i går, Fellesskapet i dag]. Istanbul: Agora, 2010. Avc1 skal selv ha vært tilhenger av Gülen-bevegelsen på 8otallet, og var ifølge tidligere politiske fanger også involvert i tortur. Se «Ezanı duyunca iskenceyi bırakır namaza girerdi» [«Da han hørte bønneropet, pleide han å stoppe torturen og gå for å be»], i Taraf (dagsavis), 2.2.2010.

45 Nebiler, Halil. Devletin Güvenlik Mahkemeleri [Statens sikkerhetsdomstoler]. Istanbul: Sel Yayınları, I990, og Devlet Güvenlik Mahkemeleri [Statssikkerhetsdomstolene]. Ankara: Ankara Barosu İnsan Hakları Komisyonu, I999.

46 Min ganske frie oversettelse er basert på den tyrkiske utgaven av KCKs deklarasjon, som kan leses på http://tr.wikisource.org/wiki/KCK_Sözlesmesi. En engelsk oversettelse av deler av deklarasjonen finnes på http://www.freemedialibrary.com/index.php/ Declaration_of_Democratic_Confederalism_in_ Kurdistan.

47 Sorusturma No. 2009/1827, Esas No. 2009/827, Iddianame No. 2009/786.

48 Sorusturma No. 20II/1903, Esas No. 2012/159, Iddianame No. 2012/123.

49 Sorusturma No. 2011/2196, Esas No. 2012/225, Iddianame No. 20I2/168.

50 «KCK'da 2000 Tutuklu» [«2000 anholdte i KCKsaken»] i Radikal (dagsavis), I.7.20I2.

5I Ahmet Insel: «Sanki BDP yargılanıyor», i Radikal (dagsavis), I8.4.20I2.

52 Sinclair-Webb, Emma: Protesting as a Terrorist Offense: The Arbitrary Use of Terrorism Laws to Prosecute and Incarcerate Demonstrators in Turkey. Human Rights Watch, 2010, s. 19-33.

53 Forskjellige estimater finnes i Tutuklu Ögrenciler Raporu [Rapport om de anholdte studentene]. Çagdas Hukukçular Dernegi, 20II, http://www.chd.org.tr/ haber_detay.asp?haberID=592; Aygün, Hüseyin: Tutuklu Ögrenciler Ile Ilgili Hazırlanan Raporun Tam Metni [Hele teksten til rapporten om de anholdte studentene], 20II, http://www.huseyinaygun.org/gundem/komisy on-calismalari/303-tutuklu-ogrenciler-ile-ilgili-hazir lanan-raporun-tam-metni.html; Tutuklu Ögrenciler Raporu [Rapport om de anholdte studentene]. Tutuklu Ögrencilerle Dayanisma Insifiyatifi, 20I2, http://www. bianet.org/files/doc_files/000/000/624/original /TÖDI_tutuklu_Ögrenciler_raporu.docx.

54 Radikal, 2.2.20I2.

55 Radikal, I9.9.2008. 